Jurnal Ekonomi Pembangunan, 18 (2), 2017, 205-212

\title{
An Empirical Investigation of Outsourcing Implementation in The Indonesian Manufacturing Industry
}

\author{
Siti Aisyah Tri Rahayu, Lukman Hakim, Malik Cahyadin* \\ Faculty of Economics and Business \\ Universitas Sebelas Maret, Indonesia \\ *Corresponding Author: malikcahyadin@gmail.com
}

Recieved: July 2017 | Revised: November 2017 | Accepted: November 2017

\begin{abstract}
This study aims to identify regulations and analyze the determinants of outsourcing implementation in the Indonesian manufacturing industry using an analyctic hierarchy process (AHP). We examines both the Indonesian Labor Law-Act No. 13/2003 and the Regulation of Minister of Manpower and Transmigration No. 19/2012 on Conditions for Outsourcing the Implementation of Work to Other Companies. The results suggest that business efficiency, human resource development plan, types of outsourcing, wage level and worker incentive, recruitment and training cost, skilled worker and productivity, recruitment process, and goverment regulation are the priority factors to implement outsourcing in Indonesian manufacturing industries.
\end{abstract}

Keywords: Outsourcing, Manufacturing industry, Determinant factor, Policy, AHP JEL Classification: J08, J23, J41, J53

How to cite: Rahayu, S., Hakim, L., \& Cahyadin, M. (2017). An Empirical Investigation of Outsourcing Implementation In The Indonesian Manufacturing Industry. Jurnal Ekonomi Pembangunan: Kajian Masalah Ekonomi dan Pembangunan, 18(2), 64-71. doi:https://doi.org/10.23917/jep.v18i2.4671

DOI: https://doi.org/10.23917/jep.v18i2.4671

\section{Introduction}

The outsourcing phenomenon is becoming more and more important for the government, manufacturing sector and workers in Indonesia. Despite the economic advantages of outsourcing, such as cost reduction in terms of labor as well as research and development; investments in assets, production, and technology; resource efficiency and cost saving, there is no denying that the implementation of outsourcing can lead to undesirable consequences, such as discrimination and exploitation of workers (Tjandraningsih, Herawati and Suhadmadi, 2010). Wiratraman (2007) identifies various consequences of the phenomenon of outsourcing in Indonesia, including a neoliberal approach of the industry, reduction of employee incentives, inconsistency in developing employment relations, lack of job security, exploitation of workers, and social tensions.

This study examines two research problems as follows: government regulations on labor outsourcing in Indonesia and the factors of labor outsourcing in Indonesia's manufacturing industry. The analysis was supported by the significant research conducted by McKinsey and Company (2004) as well as Munch and Skaksen (2005).

Burhany (2009) found that outsourcing and core competency strategies have affected firm financial performance of the manufacturing companies in Indonesia. According to Utomo 


\section{Jurnal Ekonomi Pembangunan, 18 (2), 2017, 205-212}

(2014) there are five major problems to implement outsourcing in Indonesia. First, it seems essential to evaluate current government regulations and policy. Second, workers' rights are not sufficiently protected by the Indonesian law. Third, it is necessary to differentiate types of outsourcing in terms of core and non-core business activities. Fourth, the issue concerns relations between outsourcing agent (company) and outsourcing user. Fifth, the problem concerns the labor outsourcing itself. The studies about issues related to outsourcing in other countries were conducted by Anderton and Brenton (1998), Kotabe and Mol (2004), McKinsey \& Company (2004), Munch and Skaksen (2005), Kremic, Tukel and Rom (2006), Chongvilaivan, Hur and Riyanto (2009)

Findings of this study include analysis of government regulations on outsourcing: the Indonesian Labor Law - Act No. 13/2003, and the Regulation of Minister of Manpower and Transmigration No. 19/2012 on Conditions for Outsourcing the Implementation of Work to Other Companies. The research confirms that the main factor of outsourcing implementation in Indonesia is business efficiency.

The determinants of outsourcing are widely discussed in numerous analyses. Islam and Sobhani (2008) claim that these factors include: $\begin{array}{ll}\text { a) reduction in operating costs, } & \text { b) resource }\end{array}$ efficiency in terms of business activities of the company, and c) lack of internal resources and an access to e.g. specialized skills. Dorasamy, et al (2010) conclude that the decision to outsource services, such as accounting, depends on seven main factors: a) cost, $\quad$ b) resource, c) competency, d) risk connected with outsourcing, e) operations management, f) firm size, and g) type of industry. On the other hand, Seth and Sethi (2011) distinguish certain types of outsourcing decisions, such as: a) organizationally-driven, b) improvement-driven, c) financially-driven, d) revenue-driven, e) cost-driven, and f) employeedriven.

According to Gaspareniene, Remeikiene, and Startiene (2014) there are three types of the determinants of outsourcing that can have both positive and negative impact on a business activity of a company. Consequently the authors distinguish financial, strategic and other factors of outsourcing. Firstly, outsourcing can lead to specific results for the company in the sphere of finance. In this case the advantages of outsourcing include: a) cost reduction of employment, research and development, investments in assets production, and technology; b) resource efficiency and cost saving; and c) converting costs from fixed to variable. However, it is worth pointing out that the negative consequences of outsourcing can include: a) risk of offshoring (hidden cost), and b) unclear cost-benefit relation. Secondly, it is possible to distinguish both positive and negative strategic effects of outsourcing for a company. The positive effects include: a) focus on a core activity, b) suppliers' investments and technologies, c) improve services and quality, d) gain flexibility, e) share risk, f) process improvement, and g) reduce time to market. Nevertheless, it is necessary to point out certain risks, such as: a) loss of core activity and competency, b) risk of dependency, c) loss of strategic flexibility, and d) poor quality of supply.

Finally, specific effects of outsourcing can concern other spheres of the companies' activities. The positive effects are as follows: a) consumer satisfaction, and b) following fashion. However, outsourcing can also cause: a) fall in employee's morale, and b) declining job security.

\section{Method}

The source of the primary data in this research is the survey based on purposive sampling method. The questionnaire was distributed to fifty respondents employed in various Indonesian companies that outsource workers in the manufacturing industry. The respondents are supposed to provide the information about the determinants of implementing outsourcing schemes in the companies.

This research uses analytical hierarchy process (AHP). These methods, which are not 
widelyused to analyze and explain the phenomenon of outsourcing, are supposed to increase value of this research. Therefore, the main purpose of the analysis is to find main factors of outsourcing in Indonesia's manufacturing industry.

The AHP is a method to make a decision based on expert perception (Saaty, 2008). Consequently, four axioms are applied including reciprocal comparison, homogeneity, independence and expectation. These axioms were used in the AHP analysis as follows:

Researcher conducted the interviews with the respondents concerning reasons for outsourcing in Indonesia.

Researcher identified and classified the opinions at point (a) into eight groups of factors, which are as follows: Government regulations (KP) on outsourcing, including five indicators, which are described according to the Labor Law; Recruitment process (PRK) of outsourced workers, including two indicators: the importance of outsourcing in recruitment process and work contract process; Recruitment and training cost (BPP) of employee outsourcing, which consists of three indicators explaining the cost of recruitment and training of outsourced workers; Type of outsourcing (JPO), which consists of four indicators. This factor confirms that the manufacturing industry has implemented several types of outsourcing; Wages and incentives (TGIP) for outsourced employees, which consists of four indicators explaining the significance of wage regulation for outsourced workers; Skills and productivity (PTP) of outsourced employees, consisting of three indicators. All of them reflect the important role of an outsourcing scheme in order to provide skilled labor. Meanwhile, Human resource development plan (KJK) for outsourced workers, which consists of three indicators explaining the decision of the manufacturing industry to introduce human resource development plan. Business efficiency (EBU) of outsourcing, described by three indicators.

The determinants of outsourcing are included in eight groups analyzed with AHP procedure.
It consists of pair-wise comparison matrix, eigenvector (normalized) matrix, consistency index and consistency ratio.

\section{Results and Discussion}

The concept of outsourcing was implemented in order to support non-core business activities of a company. However, it seems indispensable to introduce certain government regulations to supervise and evaluate the implementation of this phenomenon Thus, it is necessary to emphasize that Indonesia has established certain regulations on outsourcing, which are as follows: the Labor Law - Act No. 13/2003 and the Regulation of Minister of Manpower and Transmigration No. 19/2012 on Conditions for Outsourcing the Implementation of Work to Other Companies. The purpose of these documents is not only to regulate outsourcing procedures, but also provide guidance in the implementation of the outsourcing process in Indonesia.

According to the Labor Law - Act No. 13/2003 companies in Indonesia have to follow specific regulations:

a. A company can transfer a part of a business activity to other companies.

b. The job that can be transferred as follows: a) non-core activity only, b) direct or indirect demand, c) supporting system, and d) relevance with production process.

c. A company should provide: a) employment contract, b) wage and welfare guideline, and c) job instruction.

The Regulation of Minister of Manpower and Transmigration No. 19/2012 on Conditions for Outsourcing the Implementation of Work to Other Companies legalized outsourcing according to certain rules, which are as follows:

a. Providing information on: a) rights and responsibilities each of the parties (company and worker), b) job security, and c) competency and skill of worker.

b. Concerning activities in the field of: a) cleaning services, b) catering, c) security, 
d) supporting services in the mining and petroleum industry, and e) transportation for workers.

c. Preparing employmentcontracts according to specific requirements: a) sustainable employment, b) workers' rights (right to leave, social insurance, holiday allowance, rest at least one day a week, and compensation andothersaccording to certain rules/employment contract).

In contrast, several findings of this research confirm certain weaknesses of outsourcing in Indonesia. According to this analysis it is possible to emphasize certain conclusions concerning outsourced workers:

a. Outsourced employees should be treated equally with direct employees in terms of wage payment and incentives.

b. Outsourced employees should have a right to join labor unions.

c. Companies should implement and follow human resource development plans in order to provide their employees specific career path in future.

This research was carried out with sample size of fifty respondents, managers of both state and private-own enterprises in Indonesian manufacturing industry. Their companies were outsourcing employees, both men and women, according to the contracts for definite (temporary contracts) as wells as indefinite period (permanent contracts). The sample of respondents is dominated by managersworking in privatecompanies. It is worth pointing out that managers of the private companies constitute $90 \%$ of respondents, whereas managers of the state companies only $10 \%$.

The second information provided by the respondents is the percentage of men and women among outsourced workers. According to the survey the vast majority consists of male workers. In general, about $70 \%$ of outsourced workers are men, whereas women comprise $30 \%$ of outsourced labor in both state-owned and private companies.

Finally, the respondents also provided the information concerning the period of the outsourcing agreement. The Indonesian manufacturing industry applies both definite and indefinite term employment contracts. The temporary contract is applied in case of outsourcing employees for a period not longer than two years with an option to extend the agreement. On the other hand, the indefinite term employment agreement for outsourced employees is appliedin case of contracts in accordance with the Regulation No. 19/2012.

The sorting process of the determinants of workers' outsourcing in the Indonesian manufacturing industry has been conducted based on the Expert Choice method and the Analytic Hierarchy Process (AHP) procedures in order to evaluate the importance of these factors. Furthermore, it is necessary to emphasize that the Expert Choice explains the preferences of a respondent who understands and has an extensive knowledge of the outsourcing process.

The first step of the AHP method is creating a pairwise comparison matrix in order to estimate relative importance of the determinants of workers' outsourcing. The value of each factor was estimated according to the preferences of the respondents. These values were used to compose the eigenvector (normalized) matrix.

The second procedure of AHP is computing an eigenvector (normalized) matrix, which describes the value of an eigenvector and a normalized eigenvector. The value of eigenvector is based on pairwise comparison of the determinants of labor outsourcing. Consequently, the normalized eigenvector was obtained from comparing the eigenvector value of each factor. It is also the basic value for composing consistency index.

The third step of AHP method is consistency index that provides two calculation results: weighted rating and lambda. The weighted rating was obtained from dividing the value of pairwise comparison matrix to normalized 
eigenvector of each factor of workers' outsourcing. The lambda was computed by dividing the value of weighted rating to normalized eigenvector. The value of lambda is also a base to calculate the value of consistency index. Calculation results are presented in Table 1.

According to the calculation results in Table 1 it is visible that the highest value of weighted rating (1.4732) is Row 8 with Business Efficiency factors(EBU). On the other hand, the lowest value of weighted rating (0.5441) is Row 1 with government regulations on outsourcing (KP).

Munch and Skaksen (2005) identify that wage and skill of worker can affect outsourcing decision. Kremic, Tukel and Rom (2006) identify factors that support outsourcing decision are cost of production, business environment, business strategy, and business characteristics. Islam and Sobhani (2008) conclude that there are three factors affect outsourcing decision are improve company focus, access to world class capability and unavailability of internal resources. Meanwhile, Chongvilaivan, Aekapol, Jung Hur and Yohanes Eko Riyanto (2009) conclude that "(1) the downstream materials and service outsourcing have a positive impact on the wages of skilled workers relative to those of unskilled workers and the relative demand for skilled workers, while upstream materials outsourcing has the opposite impact. (2) the nature of the relationship between capital inputs and skilled workers depends on the types of capital input employed in the production process."

Dorasamy, et al. (2010) identify factors affect outsourcing decision are Cost, Resources, Competencies, Risks of Outsourcing, Operation Management, Firm Size, and Types of Industry. Meanwhile, Heng, Thangavelu and Kee (2009) and Chongvilaivan and Thangavelu (2013) conclude that productivity can encourage outsourcing decision.

The final procedure of AHP is Consistency Ratio, which is calculated by dividing the value of consistency index to Alonso-Lamata's table. The research proved that all AHP's value of the factors of labor outsourcing were consistent. Table 2 provides the information about the priorities of these factors.

According to the results from Table 2 the most important factor of labor outsourcing is business efficiency. This finding of the research suggests that labor outsourcing in the Indonesian manufacturing industry is considered particularly important owing to its role and impact on business operations. However, it would seem necessary to point out that government regulations are perceived by Indonesian manufacturing companies as the least important factor. It means that Indonesian companies do not perceive these regulations as crucial and obligatory and furthermore, in many cases they do not follow them.

Table 1. Weighted Rating of Outsourcing Factors

\begin{tabular}{llll}
\hline & Weighted Rating & \multicolumn{3}{c}{ Lambda (max) } \\
\hline Row 1 (KP) & 0.5441 & Row 1 (KP) & 8.5297 \\
Row 2 (PRK) & 0.7767 & Row 2 (PRK) & 8.5297 \\
Row 3 (BPP) & 0.9206 & Row 3 (BPP) & 8.5297 \\
Row 4 (JPO) & 1.3768 & Row 4 (JPO) & 8.5297 \\
Row 5 (TGIP) & 1.1188 & Row 5 (TGIP) & 8.5297 \\
Row 6 (PTP) & 0.8943 & Row 6 (PTP) & 8.5297 \\
Row 7 (KJK) & 1.4251 & Row 7 (KJK) & 8.5297 \\
Row 8 (EBU) & 1.4732 & Row 8 (EBU) & 8.5297 \\
\hline
\end{tabular}

Source: Primary Data (processed)

Note: Consistency Index is 0.0757 
Jurnal Ekonomi Pembangunan, 18 (2), 2017, 205-212

Table 2. The Triorities of the Factors of Labor Outsourcing in the Indonesian Manufacturing Industry

\begin{tabular}{lcc}
\hline \multicolumn{1}{c}{ Factors } & $\begin{array}{c}\text { Normalized } \\
\text { Eigenvector }\end{array}$ & Priority \\
\hline Government regulations (KP) on outsourcing & 0.0638 & 8 \\
Recruitment process (PRK)of outsourced workers & 0.0911 & 7 \\
cost (BPP) of recruiting and training of outsourced workers & 0.1079 & 5 \\
Types of outsourcing (JPO) & 0.1614 & 3 \\
Wages and incentive (TGIP) for outsourced workers & 0.1312 & 4 \\
Skills worker and productivity (PTP) of outsourced workers & 0.1048 & 6 \\
Human resource development plan (KJK) for outsourced workers & 0.1671 & 2 \\
Business efficiency (EBU) of outsourcing & 0.1727 & 1 \\
\hline
\end{tabular}

Source: Primary Data (processed)

Note: Consistency Ratio is 0.0538

Outsourcing factors in the Indonesian manufacturing industry are classified into eight groups. The factors have been analyzed using AHP in order to verify and evaluate their importance in the decision-making process concerning outsourcing in the industry. The analyzed factors consist of: government regulations on outsourcing, recruitment process of outsourced workers, recruitment and training cost of outsourced workers, types of outsourcing, wages and incentives for outsourced employees, skills and productivity of outsourced workers, human resource development plan of outsourced employees as well as business efficiency of labor outsourcing. Business efficiency (EBU) is perceived as the most important factor of outsourcing decision in the manufacturing industry. The value of AHP of this factor is 0.1727 that means that the companiesoptimize the outsourcing process according to the strategy based on business efficiency. Theoutsourcing strategy can be implemented easily in a technology-based company, especially in terms of outsourcing of noncore business activities. There is no denying that business efficiency approachhas a positive impact on operating income and business development in the long run.

The human resource development plan (KJK) for outsourced workers is becoming more and more importantfactorin the recruitment process according to the analysis and the value of AHP (0.1671). The human resource planning provides benefits both for a company and outsourced workers, such as improving career development as well as employees' competencies. This approach also ensures employees about job security and career opportunities.

A type of outsourcing can be considered ont only as a factor determining the outsourcing strategy itself but alsoa type of a job and a period of employment. According to the analysis the value of AHP is 0.1614. The Indonesian labor law recognizes both temporary and permanent contracts. However, the final decision concerning a period of employment is being made according todemand foroutsourced workers in each company. It is worth mentioning that companies also consider outsourcing of non-core business activities in the business development plan.

Wages and incentives (TGIP) foroutsourced workersare a significant determinant of the employment contracts. The AHP value of this factor is 0.1312 that means the outsourcing companiesconsider wages and incentivesas an important factor in their business strategies. The companies mustfollow goverment regulations on minimun wage. Besides, the incentives for the employees are perceived as an effective way to increase workers' performance and in consequence the efficiency of the manufacturing 
industry. Therefore, the incentives for employees should be considered as another support for the implementation of the outsourcing strategy within the industry.

Costs of recruiting and training (BPP) of outsourcedworkers are being consideredas a factor determining number ofemployees. The AHP value of this factor (0.1079) suggeststhat costs of recruitment and training are correlated with the number of outsourced workers. Consequently, the outsourcing strategy is the way to reduce these costs.

Skills and productivity (PTP) of outsourcedworkers are also an important factor determiningbusiness activities. The value of AHP of this factor is 0.1048 that means that the companytries to correlate this factorwith its outsourcing strategy. There is no denying that the companies that outsource employees can clearly benefit from a better business performance.

The recruitment process (CRP) of outsourced workersis becoming more and more important determinant of labor outsourcing. The value of AHP in this case is 0.0911 that provides an information that the industry recognizes the significance of this factor The advantages of labor outsourcing consist of all procedures and instruments used in the specific recruitment method.

Finally, it is necessary to emphasize that the government regulations (KP) on outsourcing are the least important factorfor the Indonesian manufacturing industry. The value of AHP of this factor is 0.0638 that means that the industrydo not perceivethese regulations as the main guidelinesfor the outsourcing strategy .

\section{Conclusion and Implication}

In summary, according to this research the priorities of the determinants of labor outsourcing in the Indonesian manufacturing industry are as follows: business efficiency (EBU), human resource development plan (KJK), types of outsourcing (JPO), wages and incentives (TGIP) for outsourced workers, costs of recruiting and training (BPP), skills worker and productivity (PTP), recruitment process (PRK), and government regulations (KP) on outsourcing.

This research suggests to government for supervising firms that conduct outsourcing workers. It can be employed in the form of making a good base data on outsourcing workers and using a control/supervise instrument for a firm. On the other hand, outsourcing workers should join to labor union.

\section{Acknowledgments}

We would like to thank the Directorate General of Higher Education for the financial support of research.

\section{References}

Anderton, Bob and P. Brenton (1998, December). "Outsourcing and Low-Skilled Workers in the UK", Working Paper Series. University of Warwick: Centre for the Study of Globalisation and Regionalisation (CSGR).

Burhany, Dian Imanina (2009, December).

"The Effect of Outsourcing Strategic Implementation and Core Competency to Company Financial Performance". Ekuitas Vol. 13 No. 4 pp. 506-525.

Chongvilaivan, Aekapol, Jung Hur and Yohanes Eko Riyanto (2009). "Outsourcing Types, Relative Wages, and the Demand for Skilled Workers: New Evidence from US Manufacturing". Economic Inquiry Vol. 47, No.1, pp. 18-33.

Chongvilaivan, Aekapol and Shandre M. Thangavelu (2013). "Outsourcing Decisions: Theory and Evidence”. National University of Singapore.

Dorasamy, Magiswary, Maran Marimuthu, Jayamalathi Jayabala, Murali Raman and Maniam Kaliannan (2010). "Critical Factors in Outsourcing of Accounting Functions in Malaysian Small MediumSized Enterprises (SMEs)". Kajian Malaysia Vol. 28, No. 2. 
Jurnal Ekonomi Pembangunan, 18 (2), 2017, 205-212

Gaspareniene, Ligita, Rita Remeikiene, and Grazina Startiene (2014). "Factors Determining Employment Outsourcing in Public and Private Sectors". Inzinerine Ekonomika-Engineering Economics Vol. 25(2) pp. 203-210.

Heng, Toh Mun, Shandre M. Thangavelu and Ng Kwan Kee (2009, January). "Outsourcing and Fragmentation in Singapore Manufacturing Industry". Paper presented at JSPS AA Science Platform International Seminar in Bangkok, January 23-25.

Islam, Md. Aminul and Farid Ahammad Sobhani (2008). "Determinants of Outsourcing Decision in the Manufacturing Industry in Bangladesh". Working Paper No. AIUB-BUS-ECON-2008-23. Bangladesh: American International UniversityBangladesh.

Kotabe, M. and M. J. Mol (2004). "Outsourcing and Financial Performance: A Negative Curvilinear Relationship". Working Paper. UK: London Business School.

Kremic, Tibor, Oya Icmeli Tukel and Walter O. Rom (2006). "Outsourcing Decision Support: A Survey of Benefits, Risks, and Decision Factors". Supply Chain Management: An International Journal Vol. 11(6) pp. 467 482.

McKinsey and Company (2004). The McKinsey Global Survey of Business Executives.
Munch, Jakob Roland and Jan Rose Skaksen (2005). "Specialization, Outsourcing and Wages". Discussion Papers (05-28, 2005). University of Copenhagen: Department of Economics.

Saaty, Thomas L. (2008). "Decision Making with the Analytic Hierarchy Process". Int. J. Services Sciences Vol. 1, No. 1.

Seth, Manisha and Deepa Sethi (2011). "Human Resource Outsourcing: Analysis Based OnLiterature Review”. International Journal of Innovation, Management and Technology Vol. 2, No. 2.

Tjandraningsih, Indrasari, Rina Herawati and Suhadmadi (2010). Discrimination and Exploitation: Working Contract and Outsourcing of Metal Industries in Indonesia. Bandung: AKATIGA-FSPMIFES.

Utomo, Laksanto (2014). "Outsourcing Problems in the Indonesian Labor System". Jurnal Lex Publica Vol. 1 No. 1.

Wiratraman, R. Herlambang Perdana (2007). The Effect of Working Contract and Outsourcing from Human Right Point of View. Gresik: Solidaritas Perjuangan Buruh Indonesia (SPBI). 